\title{
Mode Choice Modelling Between Bus and Train Under the New Normal Condition
}

\author{
Willy Kriswardhana ${ }^{1}$, Akhmad Hasanuddin ${ }^{1}$, Daud Rosyid R.A. Muntsari ${ }^{1}$ \\ ${ }^{1}$ Department of Civil Engineering, Universitas Jember, Jember, 68121, Indonesia \\ willy.teknik@unej.ac.id
}

Received 10-01-2021; accepted 15-02-2021

\begin{abstract}
The passenger movements were limited by the government policies that made new system decisions, namely large-scale social distancing policies. However, over time several regions in Indonesia have begun to end large-scale social distancing called new normal. The new normal condition has undoubtedly changed the pattern of mode choice of the passenger. Little attention has been paid to the travel mode choice under the new normal condition. Therefore, this study aims to understand the travel mode choice model of train and bus, especially in the new normal era. The primary data was collected using the stated preference online-based survey. This study performed a Binomial-Logit-Difference model. From the modelling result, $89 \%$ of the passenger will choose the bus if the train's travel fare is IDR 160,000 higher. The probability value will be equal when the bus fare is IDR 25,000 higher than the train's travel cost. It indicates that people choose the bus mode because of the travel cost factor. Directions for the future study are presented.
\end{abstract}

Keywords: bus, new normal, mode choice, train

\section{Introduction}

The Trans-Java Toll Road is a toll road network that connects various cities from west to east on Java. The Trans-Java toll road also connects Indonesia's two largest cities, Jakarta and Surabaya. The existence of the Trans-Java toll road has significantly reduced travel time between Surabaya-Jakarta and Jakarta-Surabaya. Before the Trans-Java Toll Road presence, Surabaya's travel time to Jakarta was 20 hours; now with the Trans-Java Toll Road, it can be reached in 11-13 hours. The impact of reduced travel time will undoubtedly lead to more competitive competition between the bus and train modes. However, in the new normal condition, the behaviour of travel mode choice might be changing.

The COVID-19 pandemic in Indonesia caused almost all movements or activities to be restricted to reduce transmission of the COVID-19 virus. The passenger movements were limited by the government policies that made new system decisions, namely large-scale social distancing policies. However, over time several regions in Indonesia have begun to end large-scale social distancing called new normal.

Cite this as: Kriswardhana, W., Hasanuddin, A., \& Muntsari, D.R.R.A. (2021). Mode Choice Modelling Between Bus and Train Under the New Normal Condition. Civil and Environmental Science Journal (Civense), 4(1), 84-92. doi: https://doi.org/10.21776/ub.civense.2021.00401.8 
The new normal condition has undoubtedly changed the pattern of mode choice of the passenger. In March 2020, when COVID-19 pandemic started, the transportation sector has been influenced. In Indonesia, the train passenger must have a letter confirming that the passenger is healthy. According to PT Kereta Api Indonesia (PT KAI), long-distance train customers in Java Island are required to show a negative Antigen Rapid Test result as a condition for taking a train. The test is provided by PT KAI, and it requires customers to pay more (the fee of the test is excluding from the ticket price). Meanwhile, some bus operators do not require their customers to show the health test.

Some factors influence the behaviour of travel mode choice. Travel cost is the essential attribute of mode choice, followed by travel time, punctuality, access time, and connection type [1]. The extra cost could lead to a movement of passengers' travel modes. A study in Barcelona stated that the cost variable influenced the mode choice behaviour. When the costs of travelling by car increase, the probability of rail-based transportation chosen by the customers will be higher than the car [2]. Furthermore, in Australia, customers' one-way cost is a significant factor in influencing the perceived satisfaction with train fares [3]. Some factors like income and vehicle ownership also found to be significant in influencing the mode choice behaviour in Srilanka [4]. The preference heterogeneity of mode choice in Australia was partially explained by the intercity differences, user group status, income, and trip purposes [5]

In Indonesia, some studies have developed the travel mode choice model between bus and train. A study analysing the travel mode choice from Yogyakarta to Solo stated that the train mode is more desirable than buses. The average price difference is IDR -162,000 (train is way cheaper than the bus) [6]. Similarly, some studies also stated that train mode is more preferred because the fare is cheaper than bus [7][8]. However, in the new normal condition, the extra cost of taking a train could decrease the market share. Passengers, who think that the travel fare is essential, will be influenced by the regulation.

Comparing to developed countries, the study of mode choice is less developed in developing countries [9]. Moreover, little attention has been paid to the travel mode choice under the new normal condition. Therefore, this study aims to understand the travel mode choice model of train and bus, especially in the new normal era.

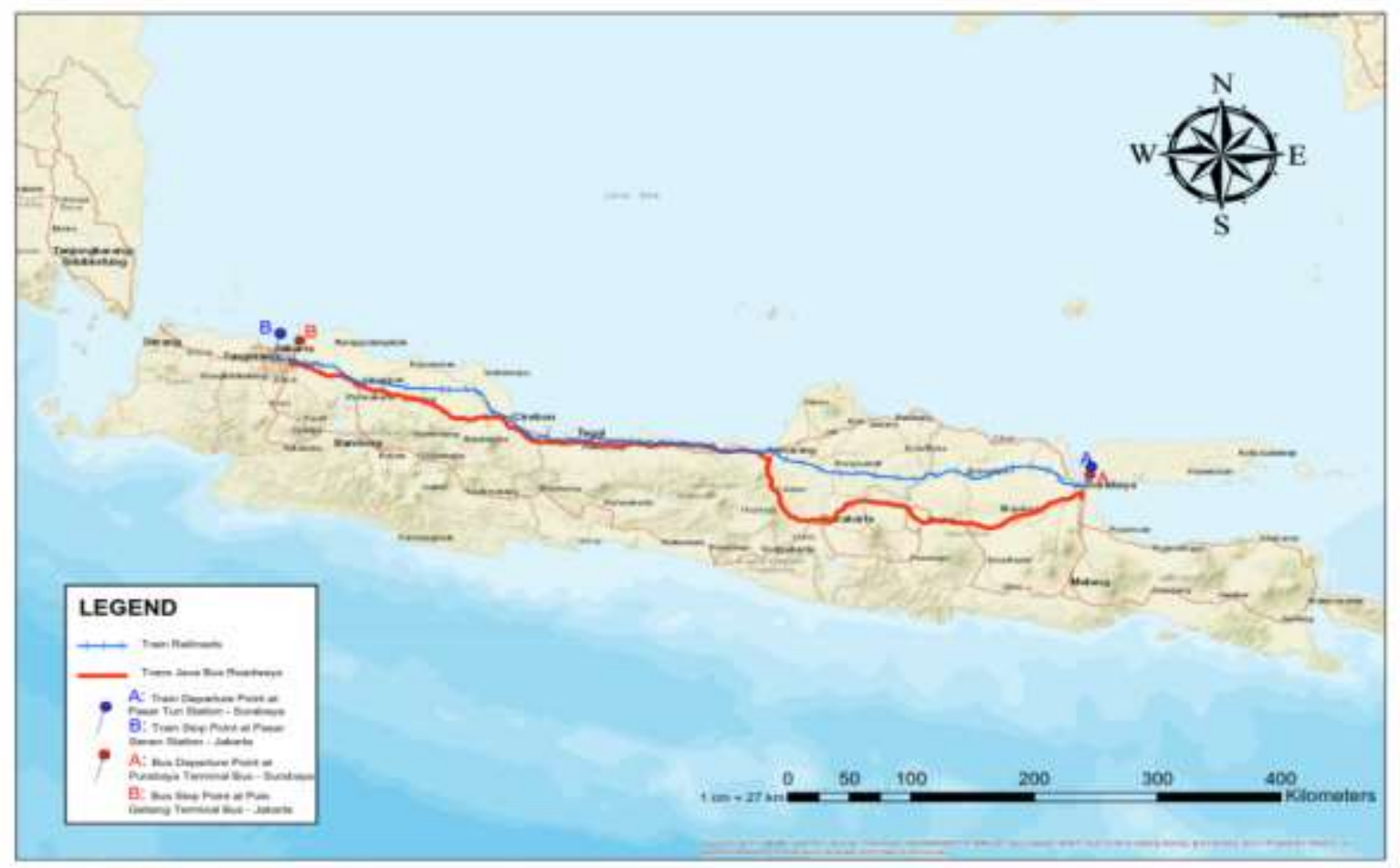

Figure 1. Surabaya-Jakarta Bus and Train Route 


\section{Material and Methods}

\subsection{Case study}

This paper studied a route of bus and train; it was Surabaya-Jakarta. Surabaya-Jakarta route represents the long-distance travel $(781 \mathrm{~km})$ (Figure 1). The research was conducted at the initial departure point for bus and train passengers. The research location and data collection were carried out in four places, including Purabaya Bus Station and Surabaya Pasar Turi Railway Station.

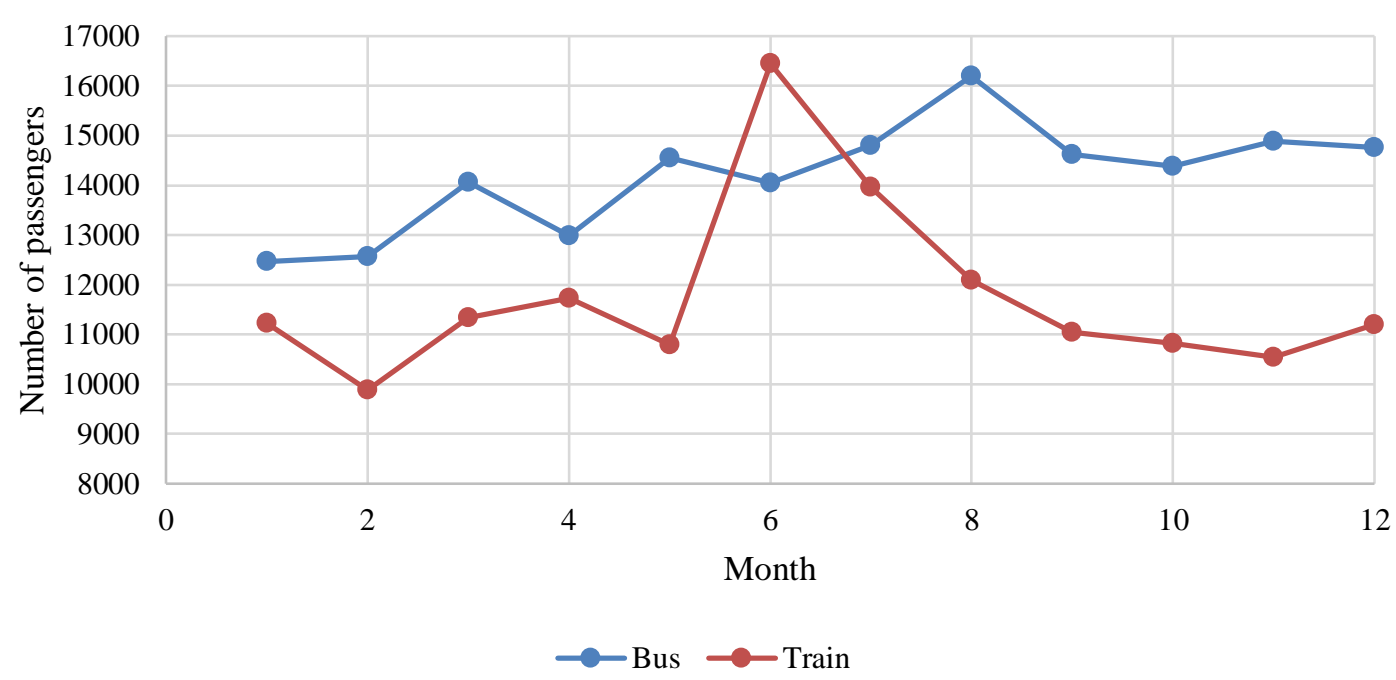

Figure 2. Number of passengers of train and bus in 2019 (source: UPT Terminal Bungurasih and PT KAI (Persero))

Figure 2 indicates that bus is the more preferable mode than train in the Surabaya-Jakarta route. People tend to travel by bus because of its flexibility and easier bus station access.

\subsection{Stated preference survey}

The primary data was collected using the stated preference online-based survey. The stated preference technique is a data collection technique refers to the approach to the opinion of respondents in dealing with various alternative choices. This technique uses an experimental design for creating alternative imaginary situations [10]. General characteristics such as gender, age, occupation, income, origin/destination, and purpose of travel were asked to the respondents. Apart from the characteristics of the users of modes, an analysis is also carried out based on considerations of cost — data obtained by distributing questionnaires to prospective bus and train passengers.

Table 1. A stated preference survey of the study

\begin{tabular}{llllll}
\hline \multirow{2}{*}{$\begin{array}{l}\text { Ticket fare of } \\
\text { bus }\end{array}$} & $\begin{array}{l}\text { Ticket fare of } \\
\text { train }\end{array}$ & Gap of ticket & \multicolumn{4}{c}{ Preferences $^{\mathrm{a}}$} \\
\cline { 4 - 6 } & fare & 1 & 2 & 3 & 4 \\
\hline IDR 375.000 & IDR 535.000 & - IDR 160.000 & & & \\
IDR 425.000 & IDR 535.000 & - IDR 110.000 & & & \\
IDR 470.000 & IDR 535.000 & - IDR 60.000 & This section was filled by the respondents \\
IDR 470.000 & IDR 485.000 & - IDR 10.000 & & \\
IDR 470.000 & IDR 435.000 & IDR 40.000 & & \\
\hline
\end{tabular}

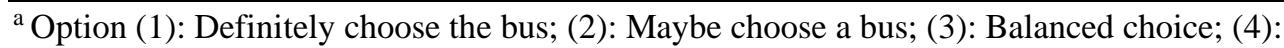
Maybe choose a train; (5): Definitely choose a train 
The number of populations in this study, both buses and trains, was taken from the average number of passengers on the Surabaya-Jakarta route (Table 1). Then, the calculation of the sample was carried out using the Slovin formula with the desired accuracy level of $95 \%$, so that the error tolerance limit (e) $=5 \%$. A total of 425 respondents filled the questionnaires. The survey was carried out from September to December 2020.

Besides the household characteristics, the mode choice characteristics were asked to the respondents. The questions regarding the mode choice characteristics are the difference in travel cost, the difference in travel time between train and bus, and access time. The cost of health test (IDR 80,000) was added to the total travel fare of the train.

\subsection{Data analysis}

This study performed a Binomial-Logit-Difference model using probability value calculations, model validation analysis, and sensitivity analysis. The Binomial-Logit-Difference Model is used to calculate the probability value of the mode choice of transportation between buses and trains. As a result of modelling the Binomial-Logit-Difference stage, the proportion of opportunities for each mode of transportation to be selected by travelers are obtained. The utility function is to measure each choice given to the respondent. This function reflects the effect of the respondent's choice on all the attributes included in the Stated Preference. Generally, utility functions are linear, as follows:

$$
U j=a+b 1 \times 1+b 2 \times 2+\cdots+b n X n
$$

Where $U j=$ choice utility $j ; a, b 1, \ldots, b n=$ model parameters and; $x 1, x 2, \ldots, x n=$ attribute value

The objective of the analysis is to determine the estimated values to which the values are referred to as the option weights or the utility component. From the model parameter values can be the relative effect of each attribute on the entire utility. After the utility component can be estimated, it can then be used for various purposes, such as determining the relative importance of the experiment's attributes and determining the utility function for model forecasting.

Furthermore, to find out the probability of each mode of transportation, the binomial logit equation is used by entering the utility value of the transportation mode obtained previously using the formula:

$$
\text { Pbus }=\frac{\text { eUbus }}{\text { eUbus }+ \text { eUtrain }}=\frac{e(\text { Ubus }- \text { Utrain })}{1+e(\text { Ubus }- \text { Utrain })}
$$

The sensitivity analysis of the model was intended to understand changes in the probability value of one mode of public transportation to illustrate this sensitivity changes in each group's attribute value. The sensitivity graph was made based on the gradual change in one of the variables; the variable is altered gradually in value by increasing and subtracting the portion with the assumption that the other variable's value is fixed.

\section{Result and Discussion}

Passengers on the Surabaya-Jakarta route can use buses or trains and other modes of transportation. Passenger transportation services from Surabaya to Jakarta, if taken by bus, can be started at Terminal Purabaya (Bungurasih). The difference in departures between buses departing from the next bus (headway) is 30 minutes. Meanwhile, passenger transportation services from Surabaya to Jakarta can be reached using the train mode, with the starting point of departure at Surabaya Pasar Turi Railway Station for the northern route. Meanwhile, if you want to go through the southern route, you can use Gubeng Railway Station as the starting point of departure.

\subsection{General characteristics of respondents}

Characteristics of passenger respondents are divided into three parts, namely socio-economic characteristics, travel characteristics, and mode choice characteristics using the Stated Preference model experiment (Table 2). The socio-economic characteristics consist of gender, age, latest education, type of work, and income in one month. The characteristics of the choice of mode using the experimental 
model Stated Preference consists of three parts of the probability of the respondent. This probability selects each category modelled between buses and trains. The first part is viewed in terms of travel cost attributes. The travel cost attribute is divided into two categories, the travel cost attribute in normal conditions and the travel cost attribute in pandemic conditions. The second part is in terms of travel time attributes. The third part is viewed in terms of the access time attribute.

Table 2. Demographic characteristics of respondents

\begin{tabular}{|c|c|c|c|}
\hline \multirow[t]{2}{*}{ Characteristics } & & \multicolumn{2}{|c|}{ Percentage } \\
\hline & & Bus & Train \\
\hline \multirow[t]{2}{*}{ Gender } & Male & 43 & 50 \\
\hline & Female & 57 & 50 \\
\hline \multirow[t]{5}{*}{ Age } & <18 years old (y.o.) & 10 & 5 \\
\hline & $18-30$ y.o. & 47 & 50 \\
\hline & 31-43 y.o. & 28 & 31 \\
\hline & $44-56$ у.о. & 13 & 12 \\
\hline & $>56$ y.o. & 2 & 2 \\
\hline \multirow[t]{6}{*}{ Last education } & Elementary school & 0 & 0 \\
\hline & Junior high school & 7 & 3 \\
\hline & Senior high school & 35 & 29 \\
\hline & Vocational study & 26 & 26 \\
\hline & Undergraduate & 27 & 33 \\
\hline & Postgraduate & 5 & 9 \\
\hline \multirow[t]{4}{*}{ Occupation } & Housewife & 6 & 0 \\
\hline & Private sector & 40 & 18 \\
\hline & Student & 34 & 32 \\
\hline & Civil servant & 20 & 29 \\
\hline \multirow[t]{5}{*}{ Income } & IDR $<1,500,000$ & 31 & 24 \\
\hline & IDR $1,500,000-3,000,000$ & 22 & 13 \\
\hline & IDR 3,000,001-4,500,000 & 25 & 22 \\
\hline & IDR $4,500,001-6,000,000$ & 14 & 25 \\
\hline & IDR >6,000,000 & 8 & 16 \\
\hline
\end{tabular}

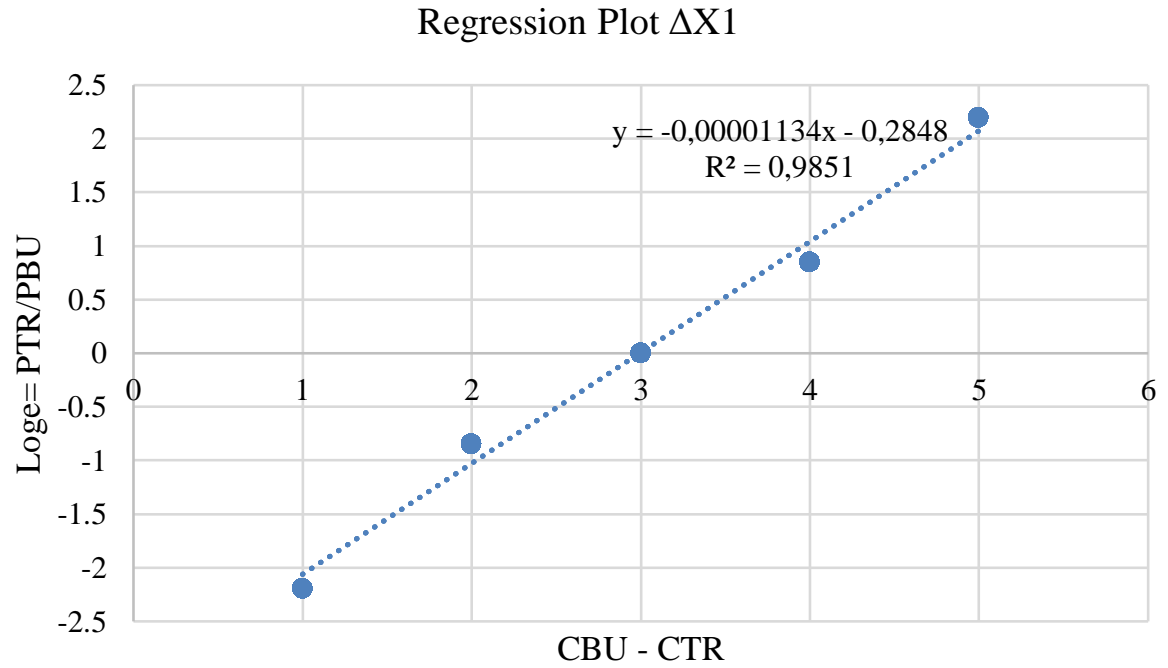

Figure 3. Simple Regression Graph Attribute Cost Difference Travel Under the Pandemic Conditions 


\subsection{Travel mode choice modelling}

The utility equation is obtained from the data input for the independent variable $\mathrm{X} 1 ; \mathrm{X} 2$; and $\mathrm{X} 3$ and the dependent variable $\mathrm{Y}$, so we get a regression equation which is the mode selection utility equation. The independent variable data, previously ordinal data (point rating), is then transformed into intervalscale data. After the regression analysis results, the modal choice utility model is obtained.

The linear regression results for bus and train passengers based on the difference in travel costs attribute in pandemic conditions $(\Delta \mathrm{X} 1)$ (Figure 3$)$.

Based on linear regression results using statistical arithmetic tools, the utility model and $\mathrm{R}^{2}$ are obtained as follows.

$$
U_{B U}-U_{T R}=-0,2848-0,00001134\left(\Delta X_{1}\right)
$$

Therefore, the model is obtained with the binomial model as follows:

$$
P_{T R}=\frac{e^{\left(U_{B U}-U_{T R}\right)}}{1+e^{\left(U_{B U}-U_{T R}\right)}}=\frac{e^{\left(-0,2848-0,00001134\left(\Delta X_{1}\right)\right.}}{1+e^{\left(-0,2848-0,00001134\left(\Delta X_{1}\right)\right.}}
$$

For example, the difference in travel costs during a pandemic condition $(\Delta \mathrm{X} 1)=(-)$ IDR 160,000 (bus tickets are IDR 160,000 cheaper than trains), the probability of bus and train passengers is obtained as follows:

$$
\begin{aligned}
& P_{T R}=\frac{e^{(-0,2848-0,00001134(-160000))}}{1+e^{(-0,2848-0,00001134(-160000))}}=0,109=10,9 \% \\
& P_{B U}=1-P_{T R}=1-0,109=0,891=89,1 \%
\end{aligned}
$$

Based on the calculation above, the model is continued with another cost difference value, then the probability of choosing the mode between bus and train is obtained. The results of the probability of choosing the mode between bus and train based on the attribute difference in travel costs in pandemic conditions are presented in the table below (Table 3):

Table 3. Probability of bus and train passengers based on the difference in travel cost attributes in the new normal condition

\begin{tabular}{cccc}
\hline$\Delta \mathrm{X} 1(\mathrm{IDR})$ & $\exp \left(\mathrm{U}_{\mathrm{BU}}-\mathrm{U}_{\mathrm{TR}}\right)$ & $\mathrm{P}_{\mathrm{TR}}$ & $\mathrm{P}_{\mathrm{BU}}$ \\
\hline-160.000 & 0.123 & 0.109 & 0.891 \\
\hline-110.000 & 0.216 & 0.178 & 0.822 \\
\hline-60.000 & 0.381 & 0.276 & 0.724 \\
\hline-10.000 & 0.672 & 0.402 & 0.598 \\
\hline 25.115 & 1.000 & 0.500 & 0.500 \\
\hline 40.000 & 1.184 & 0.542 & 0.458 \\
\hline
\end{tabular}

The regression constant is a value that affects the choice characteristics and individual characteristics that are not considered on the utility function in the mode selection. If the constant regression value is getting smaller/closer to 0 (zero), then the constant value is getting better. In this modeling obtained constant values $(-0.2848)$ and variable values $(-0.00001134(\Delta \mathrm{X} 1))$. The constant value is $(-0.2848)$, so if the two modes have the same travel costs, the difference in utility is $(-0.2848)$. Where in this condition, the bus probability value is $57.1 \%$, while the train probability value is $42.9 \%$. The probability shows a similar value when the difference of ticket fare is IDR 25,115 (Figure 4). 


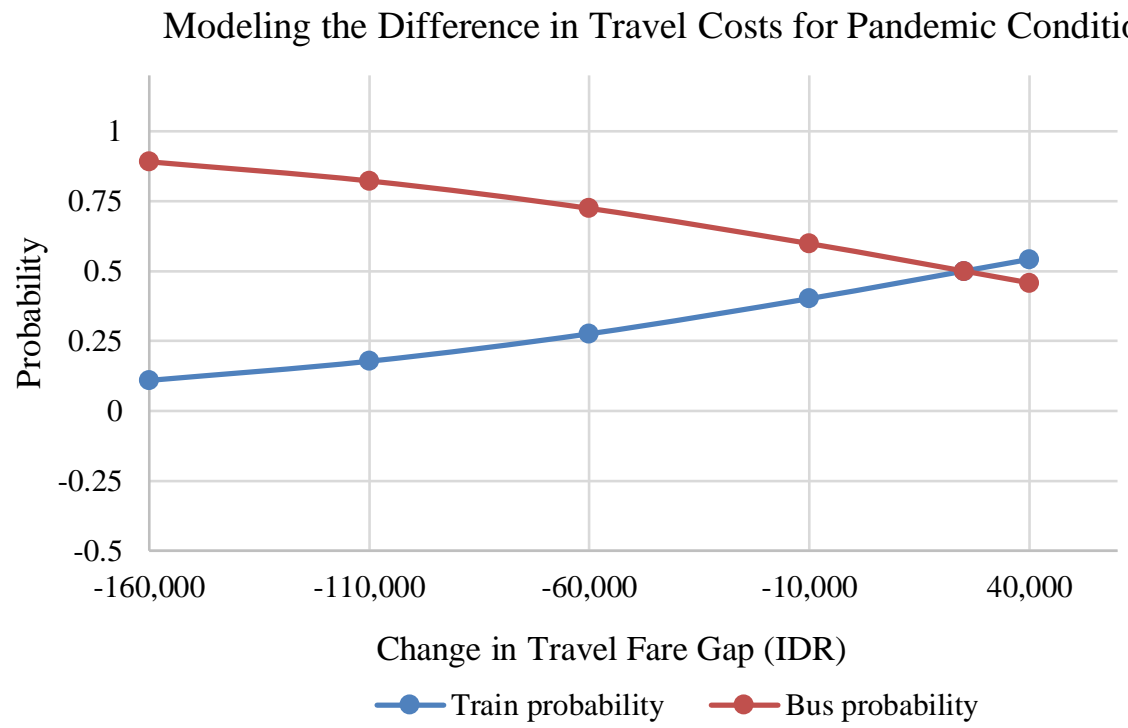

Figure 4. Probability of Bus and Train Passengers Based on the Difference in Travel Cost Attributes in Pandemic Conditions

\subsection{Sensitivity analysis}

Based on the utility value function, the fare difference between the bus mode and the train mode during a pandemic is used as an experiment when the fare difference is increased or decreased.

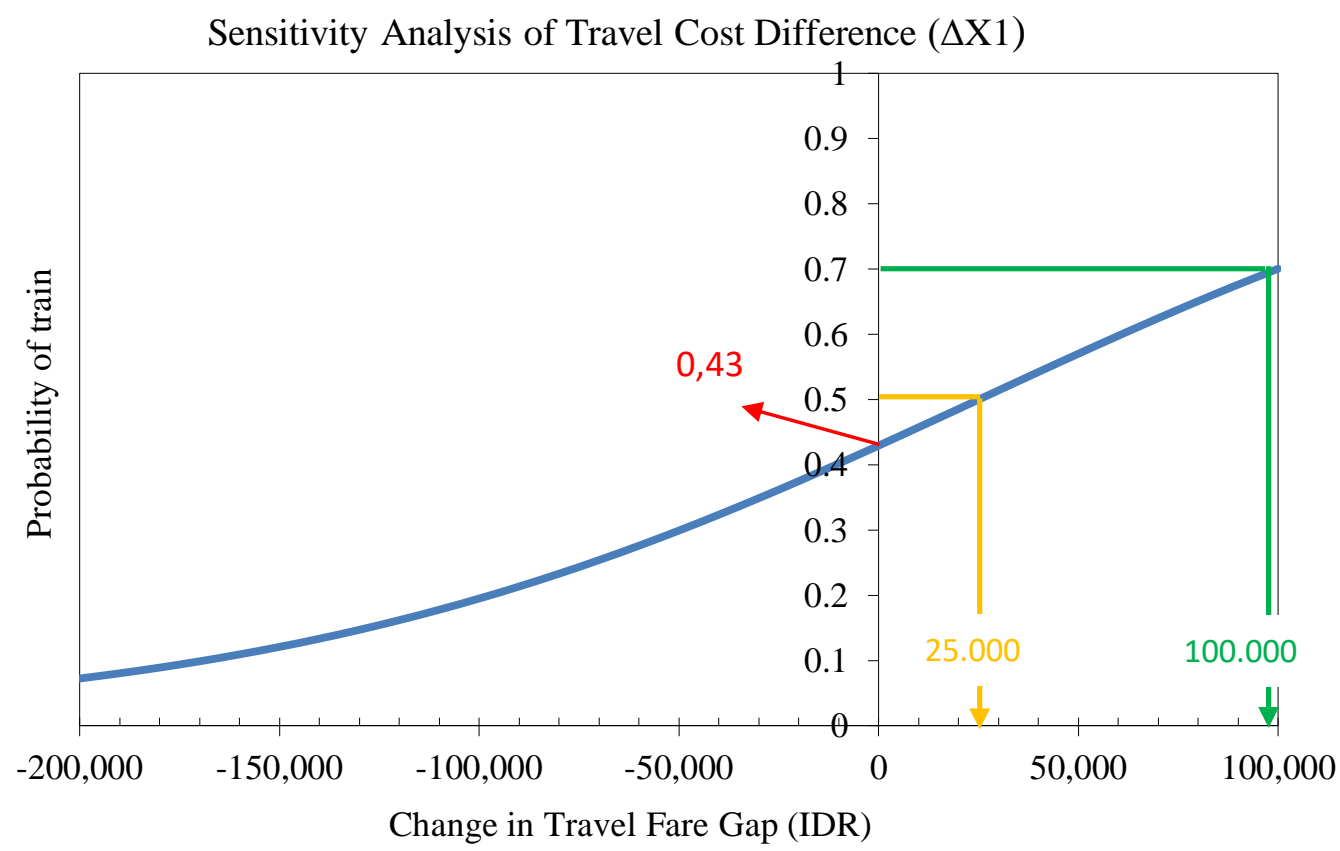

Figure 5. Sensitivity Analysis Based on the Difference in

Travel Costs in New Normal Conditions

Based on the sensitivity analysis graph of the difference in travel costs in the pandemic conditions, the calculation of the sensitivity to the variable fare gap in pandemic conditions shows that the sensitivity line slope is positive, indicating the greater probability of choosing the bus mode (Figure 5). When the travel fare difference is 0 (zero), the probability of choosing the train mode is $43 \%$, and the bus mode is 
$57 \%$. Meanwhile, when the likelihood of choosing the two modes is equal, $50 \%$, the difference in tariff is IDR 25,000 . The probability of choosing the train mode can be increased to $70 \%$ with a fare difference of IDR 100,000, meaning that the train mode must be able to reduce its fare by IDR 100,000 from the bus mode fare, or by increasing the bus mode fare to IDR 100,000 more expensive than the train.

According to the survey, respondents chose the train mode because of the health factor. PT KAI requires every passenger to wear a mask and a face shield. This requirement makes people feel safer from the danger of spreading viruses. However, this factor also makes the travel fare way more expensive. Passengers need to bring the negative Antigen Rapid Test (which costs IDR 100,000 to 300,000). Meanwhile, people chose the bus because of the travel fare was cheaper than the train mode.

\section{Conclusions}

Travel time from Surabaya to Jakarta experiences a considerable decrease because of the launching of the Trans-Java Toll Road. Consequently, the bus mode is now competing with the train mode. Meanwhile, in the new normal situation, every aspect of life has changed, including the transportation sector. Some transportation modes require the passengers to show the result of health test (generally, the negative Antigen Rapid Test), including the train mode. This requirement might be burdensome for a particular group of people because the test will cost them IDR 100,000 to 300,000. However, some people still choose to travel by train because of the health factor.

From the modelling result, $89 \%$ of the passenger will choose the bus if the train's travel fare is IDR 160,000 higher. The probability value will be equal when the bus fare is IDR 25,000 higher than the train's travel cost. It indicates that people choose the bus mode because of the travel cost factor. Meanwhile, in this new normal condition, the train operator should reduce the ticket fare by IDR 100,000 if they want a $70 \%$ probability value. Further research could develop the model of short to medium travel journey in the new normal condition. Factors related to mode choice are varied; therefore, exploring the most influencing factor of choosing travel mode in the new normal condition could be a promising idea.

\section{Acknowledgement}

We express our gratitude to the PT KAI DAOP VIII and the Department of Transportation of East Java which allowed us to access the data and do the survey.

\section{References}

[1] A. Hergesell and A. Dickinger, "Environmentally friendly holiday transport mode choices among students: The role of price, time and convenience," J. Sustain. Tour., 2013.

[2] J. Asensio, "Transport mode choice by commuters to Barcelona's CBD," Urban Stud., 2002.

[3] P. Paramita, Z. Zheng, M. Mazharul Haque, S. Washington, and P. Hyland, "User satisfaction with train fares: A comparative analysis in five Australian cities," PLoS One, 2018.

[4] R. A. M. MADHUWANTHI, A. MARASINGHE, R. P. C. J. RAJAPAKSE, A. D. DHARMAWANSA, and S. NOMURA, "Factors Influencing to Travel Behavior on Transport Mode Choice," Int. J. Affect. Eng., 2016.

[5] Z. Zheng, S. Washington, P. Hyland, K. Sloan, and Y. Liu, "Preference heterogeneity in mode choice based on a nationwide survey with a focus on urban rail," Transp. Res. Part A Policy Pract., 2016.

[6] M. H. Syahputra, A. T. Handayani, and V. D. A. Anggorowati, "ANALISIS PEMILIHAN MODA TRANSPORTASI BUS ANTAR KOTA DAN KERETA API JALUR JOGJASOLO," Equilib, vol. 1, no. 1, pp. 103-110, 2020.

[7] W. Wahab and A. Pruima, "Studi Analisis Pemilihan Moda Transportasi Umum Darat di Kota Padang antara Kereta Api dan Bus Damri Bandara Internasional Minangkabau," J. Tek. Sipil ITP, 2019.

[8] W. Kriswardhana and H. Widyastuti, "PROBABILITAS PERPINDAHAN MODA DARI BUS KE KERETA API DALAM RENCANA RE-AKTIVASI JALUR KERETA API JEMBER- 
PANARUKAN," in Seminar Nasional Teknik Sipil XI, ITS Surabaya, 2015.

[9] P. Lanzini and S. A. Khan, "Shedding light on the psychological and behavioral determinants of travel mode choice: A meta-analysis," Transp. Res. Part F Traffic Psychol. Behav., 2017.

[10] D. Pearce and E. Özedemiroglu, "Economic valuation with stated preference techniques Summary Guide," ... Prefer. Tech. ..., no. March 2002, p. 89, 2002. 